\title{
Understanding the Connection Between Social Construction and Islamic Values
}

\author{
M. Maimun*, Endah Andayani \\ Master of Social Science Education Study Program \\ Universitas Kanjuruhan Malang \\ Malang, Indonesia \\ *m.mimun01@gmail.com, endahandayani@unikama.ac.id
}

\begin{abstract}
The implementation of Islamic values in SMA Plus Miftahul Ulum Pamekasan Regency has been established and is part of the curriculum implementation. This implementation is directed to develop Islamic character of school residents such as having a culture of smiles, greetings, courtesy, mutual respect and tolerance. The objective of this study is to analyze issues related to increasingly complex sociology of society that leads to social reconstruction and inculcation of Islamic values in students. The social construction system has never been evaluated so that its effectiveness is unknown. This research is a quantitative study, with a survey approach. The data collection method uses questionnaires and documents. the data were analyzed by multiple linear regression and assisted by SPSS. The results of this study indicate that there is a significant influence between the understanding of social construction and Islamic values on the learning outcomes of student sociology.
\end{abstract}

Keywords-understanding of social construction, Islamic values, sociology learning outcomes

\section{INTRODUCTION}

Education is a social institution that has distinctive characteristics [1]. Schools and / or educational units are formal legal institutions that functionally have an important role in forming mental, knowledge [1] and human character in their social context, so that they become knowledgeable human beings who are instilled with spiritual values, faith and devotion to Allah SWT [2]. Learning in the classroom is actually a process of interaction between students and teachers, and / or students with peers or fellow students who are involved in teaching and learning activities (KBM) and or learning [3]. The interaction process that occurs in learning at schools and / or educational units is emphasized in the socialization process about scientific values (value's knowledge) and religious values (religious values) [4].

Understanding social construction of Islamic values is a view that all values, ideologies, and social institutions have components in the learning system to improve students' abilities, have an important role in determining the direction and goals of a learning process [5]. Teachers are required to master a number of abilities and skills related to the learning process starting from planning, implementing and evaluating learning [6].

Religion is a value element where religion is a solid form of legitimacy [6]. Society is man-made and on the other hand, man is the builder of society and the world, and coupled with the reality of man being a religious subject [7] then according to the social construction theory, religion will determine the social institutions that are born and exist in students, which of course does not eliminate other formers such as the existing social structures [6][7]. Thus, the color of Islam is determined by the Islamic values that are carried and believed to be true, which are then constructed to students through the educational process.

The crucial problem above, leads students to seek alternatives in order to avoid emptiness and impasse, through educational institutions. It turns out that the religion that received significant attention is Islam as a comprehensive religion that not only contains principles of morality, but also guarantees peace of mind for its followers [8][9]. Islam as a universal religion has been widely studied by educational institutions at SMA Plus Miftahul Ulum, Pamekasan Regency, which were previously considered conservative and primitive, in fact starting to have bright prospects as an alternative medium for quality Indonesian education, both in the intellectual and moral fields. Understanding Islamic values will greatly influence daily behavior [9] where religion is not only to be understood as knowledge, but how that knowledge can be applied in everyday life [9][10].

It is a known fact that Islamic values embedded in SMA Plus Miftahul Ulum, Pamekasan Regency vary, there are several aspects that are applied, starting from the aspects of Aqidah, Worship, and Morality which will later shape Islamic behavior, as applied in SMA Plus Miftahul Ulum, Pamekasan Regency. has implemented good Islamic values which aim to form Islamic character for school members such as a culture of smile, greetings, greetings, courtesy of mutual respect and tolerance, Teachers at SMA Plus Miftahul Ulum, Pamekasan Regency accompany classrooms to implement Tadarus al-Qur ' In addition, there are religious activities consisting of the 
tahfidz group memorizing 1 juz, 2 juz, 3 juz and 30 juz, and lecturing (preaching) training.

\section{MethodS}

This study uses a quantitative approach; the analysis emphasizes numerical data (numbers) processed by statistical methods, to analyze the relationship between one variable and another [11]. The population of this study were 77 students of class XI SMA Plus Miftahul Ulum Pamekasan, treated as research sample. The data collection method used questionnaires and documents. The questionnaire had been previously tested on 30 students outside the sample with validity and reliability testing. Hypothesis testing used partial test with $\mathrm{t}$ test and simultaneous test using F test. Data analysis used multiple linear regression.

\section{RESULTS AND DISCUSSION}

Based on the results of the analysis, partially and simultaneously, the variable understanding of social construction and Islamic values has a significant effect on sociology learning outcomes.

TABLE I. ANALYSIS OF T-EST

\begin{tabular}{|c|l|l|l|l|}
\hline & \multicolumn{1}{|c|}{ Variables } & t-count & t-table & Conclusion \\
\hline 1 & $\begin{array}{l}\text { Understanding of } \\
\text { social construction }\end{array}$ & 8.411 & & Significant \\
\hline 2 & Islamic values & 8.411 & 8.383 & Significant \\
\hline
\end{tabular}

In addition, the results of the analysis show that the value of tcount $=8.411>$ ttable $=8.383$ with a significance level of 0.000 so that the understanding of social construction affects student learning outcomes, and the value of tcount $=8.411>\mathrm{t}$ table $=8.383$ with a significance level of 0.000 so that Islamic values have an effect on student learning outcomes.

This is reinforced by the data analysis results which show that the percentage of influence of the independent variables, namely understanding social constructions, and Islamic values, on student learning outcomes is $67.7 \%$.

Understanding of social construction and Islamic values on student sociology learning outcomes at SMA Plus Miftahul Ulum will be optimal if it is integrated with teacher training and abilities. Teacher performance is a real behavior shown by the teacher when giving lessons to students, when carrying out teaching and learning interactions in class, including how the teacher prepares the teaching and learning process. Understanding social construction of Islamic values is a view to us that all values, ideologies, and social institutions have components in the learning system to improve student abilities, have an important role in determining the direction and goals of a learning process starting from planning, implementing and evaluate learning.

Understanding social construction is knowledge which implies that the knowledge that is in students must be pursued and at the same time the processes that make each set of knowledge a reality. Understanding social construction is knowledge that must be pursued in whatever is considered knowledge in society. Sociology teachers carry out continuous evaluations of both the process and the learning outcomes of sociology. The elements of the learning atmosphere which concern sociology learning outcomes, student attitudes, student discipline, activity and creativity in sociology learning) are components that concern sociology teachers in addition to sociology learning outcomes.

Learning outcomes are the abilities that students have after receiving their learning experiences. This is evidenced by the form of student absorption and the percentage of student success in achieving learning objectives, so it can be seen that the understanding or success in teaching and learning activities carried out by teachers and students. Student learning outcomes are carried out in a modelatic and continuous manner, so that they can become meaningful information in decision making. To improve the quality of sociology learning, it should be viewed from the input and output. The success of the learning program is only measured and the assessment of students' sociological learning outcomes. The learning process carried out by individuals will obtain learning outcomes which are changes or developments in individuals which can be in the form of attitudes, values, behavior and intellectual level. So, the learning process is an activity carried out by students in achieving sociology learning outcomes.

\section{CONCLUSION}

Based on data analysis, hypothesis testing and discussion of research results on the influence of understanding social construction and Islamic values on learning outcomes of Sociology at SMA Plus Miftahul Ulum Pamekasan, it can be concluded as follows: 1) There is a significant effect of understanding social construction, Islamic values on learning outcomes. students at SMA Plus Miftahul Ulum Pamekasan, 2) There is a significant influence on understanding social construction on student sociology learning outcomes at SMA Plus Miftahul Ulum Pamekasan, 3) There is a significant effect of Islamic values on student sociology learning outcomes at SMA Plus Miftahul Ulum Pamekasan.

\section{REFERENCES}

[1] U.A. Mu, "The Effect Of Islamic Education Learning Pai And Learning Results To Students Religious Behavior Of Stisip Widyapuri Mandiri Sukabumi Student,” Int. J. Sci. Technol. Res., vol. 6, no. 6, pp. 84-89, 2017.

[2] R. Sa'diyah, "The Influence Of Religious Motivation And Student Learning Outcome In Islamic Religious Education Towards Students Tolerance Attitude," Python Cookb., vol. 2, no. 1, p. 706, 2013.

[3] B. Kartowagiran and H. Maddini, "Evaluation Model for Islamic Education Learning in Junior High School and Its Significance to Students' Behaviours," Am. J. Educ. Res., vol. 3, no. 8, pp. 990-995, 2015.

[4] R. Abdulhamid, "The Prospects of Islamic Education Curriculum: The Case of University of Abuja," Ta'dib, vol. 22, no. 1, pp. 87-95, 2017.

[5] M.A.M. Nawi, E.A. Jamsari, M.I. Hamzah, A. Sulaiman, and A. Umar, "The Impact of Globalization on Current Islamic Education," Aust. J. Basic Appl. Sci., vol. 6, no. 8, pp. 74-78, 2012. 
[6] H. Ja'far, "Indonesian Islamic Education: Towards Science Development," Walisongo J. Penelit. Sos. Keagamaan, vol. 23, no. 2, p. 331, 2015.

[7] Z. Zurqoni, “Assessment for Islamic Education Learning and Its Impact to Student's Religiousness of Islamic University," Din. Ilmu, vol. 18, no. 2, pp. 223-236, 2018.

[8] Siswanto, The Islamic Moderation Values on the Islamic Education Curriculum in Indonesia: A Content Analysis, vol. 8, no. 1. 2020.
[9] A. Azra, Genealogy Of Indonesian Islamic Education: Roles In The Modernization Of Muslim Society, vol. 3, no. 2. 2015.

[10] F. Pohl, "On the Role of Interreligious Dialogue in Religious Studies Programs at Indonesian State Islamic Universities," J. Ecumenical Stud., vol. 50, no. 1, pp. 159-166, 2015.

[11] Winarno, "Buku Metodologi Penelitian Bisnis,” no. January, 2013. 